
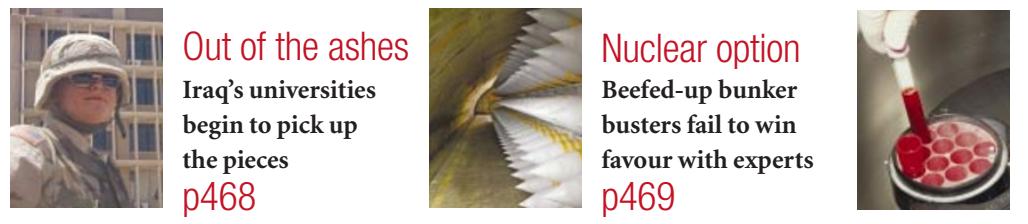

In a spin

Biologists hatch ambitious plan to track viruses p471

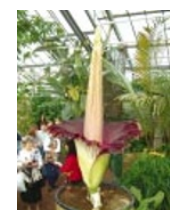

Tall story

Giant flower breaks the blooming record p472

\title{
Virus detectives seek source of SARS in China's wild animals
}

David Cyranoski, Tokyo, and Alison Abbott, Munich

Researchers investigating the source of severe acute respiratory syndrome (SARS) have turned their attention to the wildanimal markets of southern China. The move follows reports that workers and animals at the markets show high rates of infection with coronaviruses, the family to which the virus believed to cause SARS belongs.

The possible link to wild animals emerged on 23 May, when a team from the University of Hong Kong revealed that a coronavirus resembling the SARS virus had been isolated from six masked palm civets (Paguma larvata) and a raccoon dog ( Nyctereutes procyonoides) in a market in Shenzhen, in the southern Chinese province of Guangdong. Antibodies against the virus were also found in a Chinese ferret badger (Melogale moschata) from the same market.

Although the virus is not the same as that believed to cause SARS - a member of the Hong Kong team describes it as "genetically very close, but not identical” - five out of the ten civet handlers at the market had antibodies against the SARS virus in their blood.

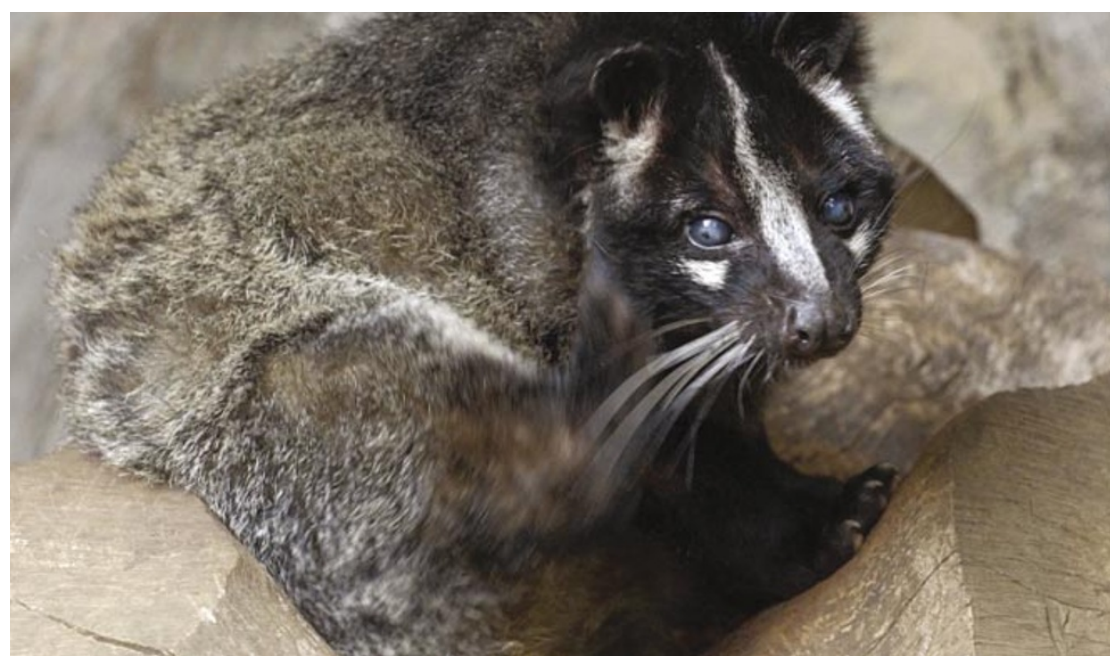

In the frame: a virus similar to that thought to cause SARS has been found in some masked palm civets.

A Chinese government team has since released results showing that 66 out of 508 animal handlers tested at markets in Guangdong had antibodies against the SARS virus.

Microbiologist Kwok-yung Yuen, who led the Hong Kong team, notes that in the

\section{BSE case rattles Canadian officials}

\section{Hannah Hoag}

The life and times of a cow from the Canadian province of Alberta are currently the subject of intense scrutiny, as officials struggle to understand how it became infected with bovine spongiform encephalopathy (BSE).

Canadian agriculture minister Lyle Vanclief announced on 20 May that the animal, which was slaughtered in January, had tested positive for BSE. Within hours, the US Department of Agriculture (USDA) banned Canadian beef imports. As of 26 May, 17 herds in Alberta, Saskatchewan and British Columbia had been quarantined.

How the cow contracted the disease continues to perplex officials. Experts say that it is likely that the animal was infected through feed made from the remains of cattle with the disease. Canada banned the use of animal remains in cattle feed in 1997, around the time that the cow was born.

Officials now have to determine what proportion of the country's cattle herd, if any, has the disease. Canada continues to allow cattle remains to be used in feed for animals such as chickens, raising the possibility that infected feed could be finding its way to cattle.

But experts are betting against a largescale outbreak or any danger to consumers. About one million cows are imported into the United States from Canada every year. Lisa Ferguson, who works on BSE-like diseases at the USDA, says that the United States runs BSE tests on these cattle, and would have detected any sign of an epidemic. general population, the level of antibodies against the SARS virus is much lower. "This suggests that the virus is jumping from wild animals to humans," he says.

Because the animal virus is similar to the SARS virus, but different from other coronaviruses, it is now a prime suspect in the hunt for the origins of SARS. The likelihood that the virus is moving the other way - from humans to animals — is diminished by ongoing work on genetic sequences of the two viruses. These analyses suggest that the animal version has an extra stretch of 29 nucleotide bases. "Viruses tend not to gain stretches of nucleotides when they jump across species," says Klaus Stöhr, a SARS expert at the World Health Organization (WHO) in Geneva.

But uncertainties remain over the exact source of the virus. Only six civets were present in the market, and the fact that they all had the virus suggests that they were infected recently. "They could have got it from another animal during transport to the markets," says Zhang-liang Chen, a molecular biologist and president of the China Agricultural University in Beijing. Chen's group did not find the SARS virus in samples from eight civets taken from other markets and in the wild in Guangdong. 